\begin{tabular}{|l|l|l||}
\hline \multicolumn{2}{|c|}{ PublisherInfo } \\
\hline \hline PublisherName & $:$ & BioMed Central \\
\hline \hline PublisherLocation & $:$ & London \\
\hline \hline PublisherImprintName & $:$ & BioMed Central \\
\hline \hline
\end{tabular}

\title{
Riboswitch ribozyme
}

\begin{tabular}{|l|c|l||}
\hline \multicolumn{2}{|c|}{ ArticleInfo } \\
\hline \hline ArticleID & $:$ & 4926 \\
\hline \hline ArticleDOI & $:$ & $10.1186 /$ gb-spotlight-20040319-02 \\
\hline \hline ArticleCitationID & $:$ & spotlight-20040319-02 \\
\hline \hline ArticleSequenceNumber & $:$ & 278 \\
\hline \hline ArticleCategory & $:$ & Research news \\
\hline ArticleFirstPage & $:$ & 1 \\
\hline \hline ArticleLastPage & $:$ & 3 \\
\hline \hline & & RegistrationDate : 2004-3-19 \\
\hline ArticleHistory & $:$ & OnlineDate \\
\hline \hline ArticleCopyright & $:$ & BioMed Central Ltd2004-3-19 \\
\hline \hline ArticleGrants & $:$ & \\
\hline \hline ArticleContext & $:$ & 130594411 \\
\hline \hline
\end{tabular}




\section{Cathy Holding}

Email: cathyholding@aol.com

So far, all repressor molecules that have been characterized are proteins. But a new study in the March 18 Nature describes a novel catalytic RNA that controls its own gene expression. These findings, say the study's authors, point to the gene control mechanisms employed by primitive organisms and suggest that modern cells retain some of these systems.

All metabolite-binding riboswitches so far discovered induce a structural change in the messenger RNA that controls gene expression by straightforward mechanisms, said Ron Breaker, associate professor in the Department of Molecular, Cellular, and Developmental Biology at Yale and senior author on the study. "The glmS ribozyme is the first riboswitch to be found that works by cutting the messenger RNA," Breaker said in an e-mail to us.

"A ribozyme in the RNA actually carries out the chemical cleavage of that RNA and thereby makes it useless," said David M.J. Lilley, director of Cancer Research UK's Nucleic Acid Structure Research Group at the University of Dundee. "So, one huge difference is it only becomes activated [to cut itself] by the binding of a small molecule - in other words, this glucosamine 6 phosphate," said Lilley, who was not involved in the study.

"If it's the first member of a very large family of riboswitch ribozymes, then that shows that ribozymes are participating in genetic control as opposed to gene expression," said Scott K. Silverman from the Department of Chemistry, University of Illinois at Urbana-Champaign. A riboswitch that is a ribozyme offers one mechanism by which encoded information, in the form of genes, could be regulated by RNA - one of the basic underlying requirements for an RNA world.

"The newly discovered molecular switch [the riboswitch] involves an RNA molecule with enzymatic activity [the ribozyme]," explained Thomas R. Cech, from the Howard Hughes Medical Institute in an accompanying News and Views article. The ribozyme is upstream of the $g \operatorname{lm} S \mathrm{mRNA}$, which generates the small sugar glucosamine-6-phosphate, involved in cell wall biosynthesis.

In the postulated 'RNA world' of 3.6 billion years ago, RNA was able to both store information and carry out chemical reactions, and life forms would not have used DNA or proteins, said Lilley. "You can get a very simple but crude genetic system that can evolve, and so you can build more complexity," he said.

It was possible to imagine that these RNAs started recruiting extra molecules, rather as enzymes use cofactors in the modern world, he added. "The advantages of amino acids were such that they kind of took over, and probably the finest creation of this RNA world was, in fact, proteins." Once there, it was possible very rapidly to get up to a modern, protein-based world, said Lilley.

Eukaryotic gene control systems typically are far more complex than metabolite-triggered selfdestruction of mRNAs, said Breaker, but this self-cutting ribozyme may persist today because the ribozyme is simply very good at what it does: it recognizes its target metabolite with great precision. 
"The RNA fragment produced when the ribozyme cleaves is also highly conserved," he said, suggesting that the ribozyme is needed to release this small RNA as well as shut down expression of the glmS mRNA.

"Perhaps the complexity that protein factors offer is the key to building complex multicellular organisms, and this might be one of the reasons why organisms of the RNA world were driven to extinction," Breaker said.

\section{References}

1. Nature, [http://www.nature.com/]

2. Ronald Breaker, [http://www.yale.edu/breaker/breaker.htm]

3. David M.J. Lilley, [http://www.dundee.ac.uk/biocentre/SLSBDIV1dmj1.htm]

4. Scott K. Silverman, [http://www.life.uiuc.edu/biochem/f_silverman.html]

5. Thomas R. Cech, [http://www.hhmi.org/research/investigators/cech.html] 